\title{
Hemşirelik Yeterliliğini Holistik Değerlendirme Ölçeğinin Geçerlilik ve Güvenilirliği \\ $\infty$
}

\author{
Emine SALDIROĞLU ${ }^{1}$, Gülengün TÜRK ${ }^{2}$
}

\section{öz}

Amaç: Bu araştırma, Hemşirelik Yeterliliğini Holistik Değerlendirme Ölçeği'nin Türkçe formunun geçerlilik ve güvenilirliğini incelemek amacı ile gerçekleştirilmiştir.

Gereç ve Yöntem: Metodolojik tipteki bu araştırma etik kurul ve kurum izinleri alındıktan sonra Aydın ilindeki bir üniversite hastanesi $(n=203$ ) ile T.C. Sağlık Bakanlığı'na bağlı bir devlet hastanesinde $(n=181)$ çalışan toplam 384 hemşire ile gerçekleştirilmiştir. Araştırmanın geçerlilik analizleri kapsamında dil geçerliliği, kapsam geçerliliği ve yapı geçerliliği (KMO and Bartlett's Testleri, faktör analizi) değerlendirilmiştir. Güvenilirlik analizleri sonucunda ölçek maddelerinin tanımlayıcı özellikleri belirlenmiş ve iç tutarlılık analizleri (madde analizleri, test yarılama analizi ve Cronbach Alfa katsayısının hesaplanması) yapılmıştır.

Bulgular: Ölçekteki her bir maddenin kapsam geçerlilik oranı 0.8 ve üzerinde olup, ölçeğin madde ortalamaları 5.89 ile 5.04 arasında değişmektedir. Ölçekteki maddeler üç faktör altında toplanmıştır. Ölçeğin madde-toplam puan korelasyon değerinin 0.51 ile $0.84(p<$ .01) arasında değiştiği ve Cronbach Alfa katsayısının 0.98 olduğu saptanmıştır.

Sonuç: Bu araştırmada Hemşirelik Yeterliliğini Holistik Değerlendirme Ölçeğinin Türkçe formunun, hemşirelerin yeterliliğini değerlendirmede kullanılabilecek geçerli ve güvenilir bir ölçme aracı olduğu sonucuna varılmıştır.

Anahtar kelimeler: Geçerlilik, güvenilirlik, hemşirelik, ölçek, yeterlilik.

\begin{abstract}
Validity and Reliability of the Holistic Nursing Competence Scale

Aim: The purpose of this study is to examine the validity and reliability of the Turkish version of The Holistic Nursing Competence Scale.

Material and Methods: This methodological study was conducted with 384 nurses working in a university hospital $(n=203)$, and a state hospital $(n=181)$ in Aydın after the ethics committee and institution permissions were obtained. Language validity, content validity, and construct validity (KMO and Barlett Tests, factor analysis) were evaluated within the scope of validity analysis. As a result of the reliability analyses, descriptive characteristics of the scale items were determined, and internal consistency analyses (item analysis, split-half analysis, and calculation of the Cronbach Alpha coefficient) were performed.

Results: The content validity rate of each item in the scale was 0.8 and above, and the item averages ranged between 5.89 and 5.04 . Items of the scale were grouped under three factors. It was determined that the item-total score correlation value of the scale ranged from 0.51 to $0.84(p<.01)$, and the Cronbach Alpha coefficient was 0.98 .

Conclusion: In this study, it was concluded that the Turkish version of the Holistic Nursing Competence Scale is a valid and reliable instrument that can be used to assess the competence of nurses. Keywords: Competence, nursing, reliability, scale, validity.
\end{abstract}

${ }^{1}$ Uzman Hemşire, Aydın Atatürk Devlet Hastanesi, Aydın, Türkiye, E-mail: ealtugs@gmail.com, Tel: $05062611758,0 R C I D: 0000000175237748$

${ }_{2}^{2}$ Prof. Dr., Aydın Adnan Menderes Üniversitesi Hemşirelik Fakültesi, Hemşirelik Esasları Anabilim Dalı, Aydın, Türkiye, E-mail: gturk@adu.edu.tr , Tel: 0 256 2138866, ORCID: 0000000186490204

Geliş Tarihi: 21 Temmuz 2020, Kabul Tarihi: 14 Aralık 2020

Atıf/Citation: Saldıroğlu E, Türk G. Hemşirelik Yeterliliğini Holistik Değerlendirme Ölçeğinin Geçerlilik ve Güvenilirliği. Hacettepe Üniversitesi Hemşirelik Fakültesi Dergisi 2021;8(1):43-50. DOI: 10.31125/hunhemsire.906944 


\section{Giriş}

Dünyanın pek çok ülkesinde hemşirelik bakımının önemi giderek artmaktadır. Sağlık bilimlerindeki ilerlemelere paralel olarak hastalıkların tedavi edilebilmesiyle birlikte bireylerin hemşirelik bakımından beklentisi de önemli ölçüde artmıştır. Değişen ve yenilenen sağılık hizmetleriyle bakıma kanıt oluşturmak, hasta güvenliğini sağlamak, uygulamaları kanıta temellendirmek ve bunların sonucunda bakımın klinik sonuçlarına odaklanmak gibi unsurlara daha fazla önem verilmektedir. Sağlık hizmetlerindeki dinamizmi yakalamak için sağlık çalışanlarının kendilerini sürekli yenilemeleri bir zorunluluk haline gelmiştir. Yaşanan bu gelişmeler hemşirelikte yeterlilik kavramını gündeme getirmiştir. Hemşirenin bakımını doğru ve etkili bir şekilde yapabilecek yeterlilikte olması gerekir ${ }^{1}$.

Yeterlilik mesleki standartlar içerisinde temel bir bileşen olarak belirtilmektedir ve hemşirelikte yeterlilik yüksek kalitede, etik değerlere uygun ve güvenli hemşirelik bakımını sağlamak için hayati öneme sahiptir ${ }^{2,3}$. Yeterlilik öğrencilikle başlayan ve meslek hayatı boyunca devam eden bir süreçtir. Hemşirelerin temel sorumluluklarını yerine getirirken bu süreci başarıyla tamamlamaları beklenmektedir. Sürekli yenilenen teknolojiyle gelişen sağlık bakımı, hemşirelerin farklı meslek gruplarıyla bir arada olmalarını zorunlu kılan çalışma ortamı, sağlık yönetiminde etkili olan maliyet etkin politikalar ve tüm bunların yanı sıra hemşirelik bakımından beklentileri giderek artan hastalar hemşirelerin mesleki uygulamalarını yerine getirmelerini giderek zorlaştırmaktadır. Bu ortam içerisinde hemşirelerin profesyonelliklerini arttırabilmek ve kendilerinden beklenen hasta bakımını en doğru ve güvenli şekilde yerine getirebilmek için yeterliliklerini değerlendirmeleri ve geliştirmeleri gerekmektedir. Hemşirelerin yeterlilik seviyesinin değerlendirilmesi, hemşirelik uygulamalarını ve hasta bakım kalitesini etkiler.

Geçmişten günümüze birçok yeterlilik tanımı yapılmıştır. Benner, While ve Nagelsmith yeterliliği 'istenen sonuçları elde edecek şekilde performans gösterme' olarak tanımlamıştır ${ }^{4-6}$. Del Bueno yeterliliği bilgi ve becerilerin etkili uygulaması olarak ifade eder ${ }^{7}$. Yeterlilik kritik düşünmeyle birlikte kişilerarası ve teknik becerilerle etkileşim halindedir ve pratiğin bilişsel, efektif ve psikomotor alanlarını birleştirir ${ }^{8,9}$. Westera'nın ifadesiyle yeterli davranışlar her zaman bilinçli düşünmeye bağlıdır ve yeterlilik başarılı bir performansın gözlemlenmesiyle ortaya çıkan bilişsel bir beceridir ${ }^{10}$. Hemşirelik uygulamalarına bakıldığında Dünya Sağlık Örgütü hemşirenin profesyonel yeterliliğini 'bilgi, tutum, psikososyal ve psikomotor bileşenlerden oluşan bir beceri çerçevesi' olarak tanımlamaktadır ${ }^{11}$. Bazı çalışmalar yeterliliği performansla yakın ilişkili olarak nitelendirmiştir ve bu durum birçok kafa karışıklığına neden olmuştur ${ }^{5,12}$. Yeterliliği sadece performansa bağı olarak değerlendirmek hemşirelik uygulamalarının etik boyutunu, hemşirelik bakımının içerdiği entellektüelliği göz ardı etmektedir.

Hemşirenin yeterliliğini değerlendirmede kullanılan ölçekler

hemşirelik hizmetlerinin değerlendirilmesini kolaylaştırmaktadır. Yeterliliğin değerlendirilmesi için literatürde yaygın olarak kullanılan ölçekler mevcuttur ${ }^{13}$. Ülkemizde hemşirelerin bakım uygulamalarını, bakım davranışlarını ve profesyonel gelişimini değerlendiren pek çok çalışma bulunmaktadır ${ }^{14-18}$. Bu çalışmalarda, daha çok spesifik bir hemşirelik bakımı uygulamasına ilişkin hemşirelerin yeterliliği değerlendirilmiştir. Ülkemizde bu çalışmalardan farklı olarak bakımda hemşirelerin yeterliliğini değerlendiren çalışmalara rastlanmamıştır. Bu nedenle Hemşirelik Yeterliliğini Holistik Değerlendirme Ölçeğinin (HYHDÖ) Türkçe geçerlilik ve güvenilirliğinin yapılmasına gerek duyulmuştur ${ }^{19}$. Ancak araştırmanın basımı aşamasında Aydın ve Hiçdurmaz (2019) tarafından ölçeğin geçerlilik ve güvenilirlik çalışmasının İngilizce olarak yayımlandığı tespit edilmiştir ${ }^{20}$. Bu nedenle bu araştırma HYHD ölçeğinin ikinci geçerlilik ve güvenilirlik çalışmasıdır. HYHDÖ hemşirelerin genel olarak yeterliliğini değerlendirmekle birlikte yönetici hemşireler tarafından da uygulanabilir bir ölçektir.

Türkçe geçerlilik ve güvenilirliği yapılan bu ölçeğin kullanımı ile hemşirelerin bakıma yönelik kendilerini değerlendirebilecekleri, yeterliliklerinin ve gelişimleri için gereksinimlerinin farkında olmalarının sağlanacağı düşünülmektedir. Böylece hemşirelerin yeterliliğinin artması ile hasta bakım kalitesinin, profesyonelliğin ve mesleki saygınlığın artması beklenmektedir.

\section{Araştırmanın Amacı}

Bu çalışmanın amacı, Takase ve Teraoka tarafından 2011 yılında geliştirilen Hemşirelik Yeterliliğini Holistik Değerlendirme Ölçeğinin ülkemizdeki hemşirelerin kullanımı için geçerli ve güvenilir bir ölçüm aracı olup olmadığını incelemektir.

\section{GEREÇ ve YÖNTEM}

\section{Araştırmanın Türü}

Bu araştırma Hemşirelik Yeterliliğini Holistik Değerlendirme Ölçeğinin Türkçe formunun geçerlilik ve güvenilirliğini belirlemek amacıyla yapılmış metodolojik türde bir çalışmadır.

\section{Araştırma Evren ve Örneklemi}

Araştırmanın evrenini 1 Temmuz 2016-15 Mart 2017 tarihleri arasında Aydın ilindeki bir üniversite hastanesi ( $n=599)$ ile T.C. Sağlık Bakanlığı'na bağlı bir devlet hastanesinde çalışan $(n=243)$ toplam 842 hemşire oluşturmuştur.

Ölçek geçerlilik ve güvenilirlik araştırmalarında örneklemdeki kişi sayısı belirlenirken ölçekteki madde sayısının en az beş katı olmak üzere on katı kişiye ulaşılması hedeflenir ${ }^{21}$. Bu bilgi doğrultusunda HYHDÖ 36 maddeden oluştuğu için araştırmada maksimum kişiye ulaşılması hedeflenmiş, \%10 oranında veri kaybı olabileceği düşünülerek 396 hemşireye ulaşılması planlanmıştır. Ölçek maddelerini tam olarak yanıtlayan toplam 384 hemşire araştırmanın örneklemini oluşturmuştur. Araştırmaya katılmayı kabul etmeyen, hasta bakımından primer sorumlu olmayan (poliklinik, kan alma vb.), ölçek maddelerini eksik yanıtlayan hemşireler araştırma kapsamı dışında bırakılmıştır. Anket formlarının hemşirelerin öz bildirimine dayalı olarak doldurulması sağlanmıştır. Anket formlarının yanıtlanması için hemşirelerin az yoğun oldukları zaman 
dilimleri tercih edilmiş ve doldurulan formlar hemşirelerden teslim alınmıştır.

\section{Veri Toplama Araçları}

Araştırma verilerinin toplanmasında; Hemşire Tanıtım Formu, Hemşirelik Yeterliliğini Holistik Değerlendirme Ölçeği kullanılmıştır.

Hemşire Tanıtım Formu: Bu form araştırmacılar tarafından oluşturulmuştur ve hemşirelere yönelik tanıtıcı özelliklere ilişkin 10 sorudan oluşmaktadır. Bu formda araştırmaya katılan hemşirelerin yaşı, cinsiyeti, eğitim durumu, çalıştığı birim, çalışma pozisyonu, çalışma süresi, çalıştığı birimde kaç hemşirenin görev aldığı, haftada kaç saat çalıştığı, hemşire sayısını yeterli bulup bulmadığı ve çalışma süresi içerisinde ortalama kaç hasta baktığı ile ilgili veriler yer almaktadır.

Hemşirelik Yeterliliğini Holistik Değerlendirme ölçeği: Bu ölçek hemşirelerin yeterliliğini belirlemek amacıyla Takase ve Teraoka tarafından 2011 yılında geliştirilmiştir ${ }^{19}$. Ölçeğin orijinali iki bölüm, beş faktör ve 36 maddeden oluşmaktadır. Ölçeğin orijinal çalışmasında Cronbach Alfa katsayısının 0.96 olduğu belirtilmiştir. Orijinal ölçekte her faktör için ayrı ayrı Cronbach Alfa değeri hesaplanmış ve bu değerlerin 'Genel Yetenek' faktörü için 0.86, 'Hemşirelik Eğitimi ve Yönetimi' faktörü için 0.93, 'Etik Odaklı Uygulama' faktörü için 0.93, 'Ekip İçinde Hemşirelik Bakımı' faktörü için 0.91 ve 'Mesleki Gelişim' faktörü için 0.88 olduğu belirlenmiştir. Hemşirelik Yeterliliğini Holistik Değerlendirme Ölçeğinin birinci bölümünde yedi maddeden oluşan 'Genel Yetenek' faktörü bulunmaktadır. Bu faktörde yer alan maddeler ile hemşirelerin mesleki davranış ve tutumlarından bağımsız olarak günlük yaşamdaki bireysel davranışları değerlendirilmektedir. İkinci bölümde 'Hemşirelik Eğitimi ve Yönetimi', 'Etik Odaklı Uygulama', 'Ekip İçinde Hemşirelik Bakımı' ve 'Mesleki Gelişim' isimli dört faktör bulunmaktadır. Bu faktörler altındaki 29 madde ile hemşirelerin mesleki yeterliliği değerlendirilmektedir.

Hemşirelik Yeterliliğini Holistik Değerlendirme Ölçeği 7'li Likert tipi bir ölçektir ve ters madde içermemektedir. 'Genel Yetenek' faktöründe hemşirelerden 'Hiçbir Zaman (1)', 'Nadiren (2)', 'Ara Sıra (3)', 'Bazen (4)', 'Sıklıkla (5)', 'Neredeyse Her Zaman (6)', 'Her Zaman (7)' seçeneklerinden birini işaretlemeleri istenmektedir. 'Hemşirelik Eğitimi ve Yönetimi', 'Etik Odaklı Uygulama', 'Ekip İçinde Hemşirelik Bakımı' ve 'Mesleki Gelişim' faktörlerinde ise 'Hiçbir Zaman Yeterli Değilim (1)', 'Çok Az Yeterliyim (2)', 'Kısmen Daha Yeterliyim (3)', 'Orta Seviyede Yeterliyim (4)', 'Neredeyse Tamamen Yeterliyim (5)', 'Tamamen Yeterliyim (6)' ve 'Son Derece Yeterliyim (7)' seçeneklerinden birini işaretlemeleri istenmiştir. Değerlendirmede verilen cevaplar 1'den 7'ye kadar puanlanmıştır. Ölçeğin değerlendirilmesinde herhangi bir derecelendirme yoktur. Ölçekte toplam puan ortalamasının yüksek olması hemşirelik yeterliliğinin yüksek olduğunu göstermektedir. Ölçekte her faktörün ve ölçeğin toplam puan ortalaması ayrı ayrı hesaplanmıştır.

\section{Veri Toplama Araçlarının Uygulanması}

Hemşirelik Yeterliliğini Holistik Değerlendirme Ölçeğinin veri toplama süreci iki aşamada gerçekleşmiştir. İlk aşamada ölçek maddeleri İngilizceden Türkçeye çevrilmiş ve ölçeğin dil geçerliliği sağlanmıştır. Ölçeğin dil eşdeğerliliği sağlandıktan sonra kapsam geçerliliği için akademisyen hemşirelerin görüşüne başvurulmuştur. Kapsam geçerliliği için uzmanlardan alınan görüşler doğrultusunda ölçeğe son şekli verilmiştir.

İkinci aşamada 1 Temmuz 2016 - 15 Mart 2017 tarihleri arasında araştırmaya katılmayı kabul eden hemşirelerden "Hemşire Tanıtım Formunu" ve "Hemşirelik Yeterliliğini Holistik Değerlendirme Ölçeği" sorularını yanıtlamaları istenmiştir. Soruların yanıtlanması ortalama 20-30 dakikadır ve gerekli açıklamalar araştırmacı tarafından yapılmıştır.

\section{Araştırmanın Etik Boyutu}

Hemşirelik Yeterliliğini Holistik Değerlendirme Ölçeğini geliştiren yazarlardan biri olan Miyuki Takase'den e-posta yoluyla yazılı izin alınmıştır. Ayrıca, bir üniversitenin Girişimsel Olmayan Klinik Araştırmalar Etik Kurulundan (Etik Kurul No: 2016/882) ve araştırmanın yapıldığı sağlık kuruluşlarından yazılı izin alınmıştır. Araştırmaya katılan hemşirelere çalışmanın amacı anlatılmış, çalışmaya katılmada gönüllülük ilkesine bağı kalınmış ve çalışmaya katılanlardan sözel onam alınmıştır. Makalenin tüm aşamalarında araştırma ve yayın etiğine uyulmuştur.

\section{Araştırmanın Sınırlılıkları}

Hemşirelik Yeterliliğini Holistik Değerlendirme Ölçeğinin orijinal dili Japoncadır. Bu araştırmada HYHDÖ'nin uluslararası bir hemşirelik dergisinde ingilizce olarak yayınlanan ve ölçeği geliştiren yazarlardan biri olan Miyuki Takase tarafından gönderilen İngilizce formu (Holistic Nursing Competence Scale) kullanılmıştır. Ölçek Japonya'da geliştirilmiştir ve ölçeğin İngilizce geçerlilik ve güvenilirliği yapılmamıştır. Araştırma sonucunda ortaya çıkan sonuçlar sadece Japonya'da yapılan araştırma sonuçlarıyla karşılaştırılabilir. Bu durum araştırmanın kısıtlılığı olarak belirtilmiştir.

\section{Verilerin Analizi}

Araştırma verilerinin analizinde, SPSS 21 (Statistical Package for Social Sciences) paket programı kullanılmıştır. Araştırmaya katılan hemşirelerin kişisel bilgileri sayı ve yüzde dağılımı ile gösterilmiştir. Ölçeğin dil geçerliliği için grup çevirisi ve geri çeviri tekniği kullanılmıştır. Kapsam Geçerliliği için ölçek maddelerine ait Kapsam Geçerlilik Indekslerini (KGi) hesaplamak amacıyla uzman görüşüne başvurulmuştur. Ölçeğin yapı geçerliliği için Doğrulayıcı Faktör Analizi ve Açıklayıcı Faktör Analizi kullanılmıştır. Öncesinde ölçeğin faktör analizi için uygun olup olmadığı Kaiser Meyer-Olkin ve Barlett's Küresellik Testi ile analiz edilmiştir.

Ölçeğin güvenilirliğini belirlemek amacıyla öncelikle madde puanlarının tanımlayıcı özellikleri (ortalama, standart sapma, toplam, min-maks) verilmiştir. Ölçeğin iç tutarlılığı için madde analizleri, test yarılama analizi yapılmış, ölçeğin tamamına ve tüm alt boyutlarına ait Cronbach Alfa katsayısı hesaplanmıştır.

\section{BULGULAR}

\section{Hemşirelerin Tanıtıcı Özellikleri}

Araştırmaya katılan hemşirelerin yaş ortalaması $33.7 \pm 8.91$ olup, \%91.4'ü kadın, \%56.6'sı lisans mezunu, \%52.9'u üniversite hastanesinde çalışmaktadır. Hemşirelerin 
\%45.3'ü dahili, \%21.4'ü cerrahi birimlerde ve \%33.3'ü yoğun bakımlarda çalışmaktadır.

\section{Dil Geçerliliği}

Hemşirelik Yeterliliğini Holistik Değerlendirme Ölçeğinin geçerliliğini test etmek amacıyla araştırmada ilk olarak ölçeğin dil eşdeğerlilik çalışmaları yapılmıştır. Öncelikle ölçek maddeleri araştırmacılar tarafından ve İngilizceyi iyi bilen, ana dili Türkçe olan uzman hemşireler, akademisyenler ve eğitimcilerden oluşan 10 kişi tarafından İngilizceden Türkçeye çevrilmiştir. Sonrasında yapılan çeviriler araştırmacılar tarafından incelenerek ölçek Türkçe olarak yeniden oluşturulmuştur. Türkçe olarak oluşturulan ölçek iki dil uzmanı tarafından İngilizceye çevrilmiştir. İngilizceye çevrilen ölçek maddeleri, orijinal ölçeğin yazarları tarafından oluşturulan ölçeğin ingilizce metniyle karşılaştırılarak uygun ifadeler seçilmiş ve İngilizce olarak tekrar oluşturulmuştur. İngilizce olarak oluşturulan ölçek bir dil uzmanı tarafından tekrar Türkçeye çevrilmiştir. Maddeler tekrar gözden geçirilmiş ve ölçeğe son şekli verilmiştir. Ölçekteki ifadelerin anlaşılır olup olmadığına karar vermek için 20 hemşireye ön uygulama yapılmış ve uygulama sonucunda ölçek maddelerinin anlaşılır olduğu sonucuna varılarak ölçeğin dil eşdeğerliliği sağlanmıştır. Ön uygulamaya katılan 20 hemşire araştırmanın örneklemi dışında tutulmuştur.

\section{Kapsam Geçerliliği}

Geçerlilik ve güvenilirlik çalışması için ölçeğin dil eşdeğerliliği sağlandıktan sonra Kapsam Geçerliliği için akademisyen hemşirelerin görüşüne başvurulmuştur. Ölçeğin KGi değerlerini belirlemek amacıyla uzmanlardan her bir maddeye 1-4 arasında puan vermeleri (4 puan = Çok Uygun, 3 puan = Oldukça Uygun, 2 puan = Biraz Uygun ve 1 puan = Uygun Değil) istenmiştir. Davis tekniği kullanılarak uzman görüşleri değerlendirilmiştir. Uzmanların yanıtlarına göre her bir ölçek maddesi için 3 ve 4 puan veren uzman sayısı, toplam uzman sayısına bölünmüştür. KGI'nin en küçük değeri 0.80 olarak kabul edilmektedir22. Yapılan hesaplamalarda KGI değeri 0.80 'in altında madde olmadığından ölçekten madde çıkarılmamış ve bütün ölçek maddeleri uzmanlardan alınan görüşler doğrultusunda değerlendirilerek ölçeğe son şekli verilmiştir.

\section{Yapı Geçerliliğ}

Hemşirelik Yeterliliğini Holistik Değerlendirme Ölçeğinin ölçtüğü niteliklerin neler olduğunu belirlemek için ölçeğin yapı geçerliliği değerlendirilmiştir. Yapı geçerliliği için faktör analizi uygulanmıştır. Verilerin, faktör analizine uygunluğu Kaiser-Meyer-Olkin (KMO) katsayısı ve Barlett Küresellik testi ile değerlendirilmiştir. Araştırma sonucunda KaiserMeyer-Olkin (KMO) katsayısı 0.974 olarak bulunmuştur. Bu değer faktör analizinin uygulanabileceğini göstermektedir. Barlett küresellik testi sonucu da ölçeğin faktör analizi için uygun olduğunu göstermiştir.

Hemşirelik Yeterliliğini Holistik Değerlendirme Ölçeğinde öncelikle bir ölçeği başka bir dile uyarlama çalışmalarında ilk olarak kullanılan, ölçeğin orijinal faktör yapısına uyup uymadığını denetlemeyi amaçlayan Doğrulayıcı Faktör Analizi uygulanmıştır. Araştırmada ölçeğe uygulanan
Doğrulayıcı Faktör Analizi sonucunda 'Genel Yetenek' başlığı altındaki 1. maddenin tek bir faktörü oluşturduğu görülmüştür. Ölçeğin 'Genel Yetenek' başlığı altındaki 1. maddesi tek başına bir faktörü temsil edemeyeceğinden ölçeğe tekrar Açıklayıcı Faktör Analizi uygulanmıştır (Tablo 1). Böylece ölçekte yer alan faktörlerin ve onları oluşturan değişkenlerin ortaya çıkarılması amaçlanmıştır.

Tablo 1. Hemşirelik Yeterliliğini Holistik Değerlendirme Ölçeği Açıklayıcı Faktör Analizi

\begin{tabular}{|l|l|l|l|}
\hline \multirow{2}{*}{} & \multicolumn{3}{|c|}{ Faktör } \\
\cline { 2 - 4 } & $\mathbf{1}$ & $\mathbf{2}$ & $\mathbf{3}$ \\
\hline Etik Odaklı Uygulama (6) & $\mathbf{0 . 8 2}$ & & \\
\hline Ekip İ̧inde Hemşirelik Bakımı (5) & $\mathbf{0 . 8 1}$ & 0.32 & \\
\hline Etik Odaklı Uygulama (5) & $\mathbf{0 . 8 1}$ & & 0.30 \\
\hline Etik Odaklı Uygulama (7) & $\mathbf{0 . 8 0}$ & & \\
\hline Ekip İçinde Hemşirelik Bakımı (4) & $\mathbf{0 . 7 8}$ & 0.35 & \\
\hline Ekip İçinde Hemşirelik Bakımı (3) & $\mathbf{0 . 7 8}$ & 0.36 & \\
\hline Etik Odaklı Uygulama (4) & $\mathbf{0 . 7 7}$ & & \\
\hline Ekip İçinde Hemşirelik Bakımı (7) & $\mathbf{0 . 7 7}$ & 0.30 & \\
\hline Etik Odaklı Uygulama (8) & $\mathbf{0 . 7 6}$ & 0.30 & \\
\hline Etik Odakı Uygulama (2) & $\mathbf{0 . 7 5}$ & 0.30 & \\
\hline Ekip İçinde Hemşirelik Bakımı (2) & $\mathbf{0 . 7 4}$ & .40 & \\
\hline Ekip İçinde Hemşirelik Bakımı (6) & $\mathbf{0 . 7 4}$ & 0.39 & \\
\hline Etik Odakıı Uygulama (1) & $\mathbf{0 . 7 3}$ & 0.33 & 0.33 \\
\hline Ekip İçinde Hemşirelik Bakımı (1) & $\mathbf{0 . 7 3}$ & 0.39 & \\
\hline Etik Odaklı Uygulama (9) & $\mathbf{0 . 7 2}$ & & 0.30 \\
\hline Mesleki Gelişim (2) & $\mathbf{0 . 7 1}$ & 0.43 & \\
\hline Mesleki Gelişim (4) & $\mathbf{0 . 6 7}$ & 0.40 & \\
\hline Mesleki Gelişim (1) & $\mathbf{0 . 6 7}$ & 0.43 & \\
\hline Etik Odaklı Uygulama (3) & $\mathbf{0 . 6 7}$ & 0.34 & \\
\hline Mesleki Gelişim (3) & $\mathbf{0 . 6 0}$ & 0.49 & \\
\hline Hemşirelik Eğitimi ve Yönetimi (3) & 0.31 & $\mathbf{0 . 7 8}$ & \\
\hline Hemşirelik Eğitimi ve Yönetimi (4) & 0.34 & $\mathbf{0 . 7 7}$ & 0.30 \\
\hline Hemşirelik Eğitimi ve Yönetimi (6) & 0.33 & $\mathbf{0 . 7 5}$ & \\
\hline Hemşirelik Eğitimi ve Yönetimi (7) & 0.42 & $\mathbf{0 . 6 9}$ & \\
\hline Hemşirelik Eğitimi ve Yönetimi (8) & 0.42 & $\mathbf{0 . 6 9}$ & \\
\hline Hemşirelik Eğitimi ve Yönetimi (5) & 0.41 & $\mathbf{0 . 6 5}$ & \\
\hline Hemşirelik Eğitimi ve Yönetimi (1) & 0.45 & $\mathbf{0 . 5 9}$ & 0.30 \\
\hline Hemşirelik Eğitimi ve Yönetimi (9) & 0.46 & $\mathbf{0 . 5 6}$ & 0.36 \\
\hline Hemşirelik Eğitimi ve Yönetimi (2) & 0.43 & $\mathbf{0 . 5 4}$ & 0.40 \\
\hline Genel Yetenek (7) & & & $\mathbf{0 . 7 9}$ \\
\hline Genel Yetenek (3) & & & $\mathbf{0 . 7 6}$ \\
\hline Genel Yetenek (5) & & & $\mathbf{0 . 7 5}$ \\
\hline Genel Yetenek (2) & & 0.31 & $\mathbf{0 . 7 4}$ \\
\hline Genel Yetenek (6) & & & $\mathbf{0 . 7 4}$ \\
\hline Genel Yetenek (4) & & & $\mathbf{0 . 7 1}$ \\
\hline Genel Yetenek (1) & & $\mathbf{0 . 6 9}$ \\
\hline
\end{tabular}

Araştırmada Açıklayııı Faktör Analizi Yöntemlerinden Temel Bileşenler Analizi Yöntemi kullanılmış ve Varimax döndürme uygulanmıştır. Uygulamalar sonucunda ölçekteki maddeler üç faktör altında toplanmıştır. Ortaya çıkan en yüksek madde faktör yükü 0.82 , en düşük madde faktör yükü 0.54 'tür (Tablo 1).

Hemşirelik Yeterliliğini Holistik Değerlendirme Ölçeğine uygulanan Açıklayıcı Faktör Analizi sonucunda ortaya çıkan faktör yapısı incelendiğinde 'Etik Odaklı Uygulama', 'Mesleki Gelişim' ve 'Ekip İçinde Hemşirelik Bakımı' başlığı altındaki maddeler Faktör 1'de, 'Hemşirelik Eğitimi ve Yönetimi' başlığı altındaki maddeler Faktör 2'de, 'Genel Yetenek' başlığı altındaki maddeler ise Faktör 3 'te toplanmıştır. 
Faktör 1'de 20, Faktör 2'de 9, Faktör 3'te 7 madde bulunmaktadır. HYHDÖ'nin faktör çözümlemesinde faktörler isimlendirilirken, Faktör 2' de 'Hemşirelik Eğitimi ve Yönetimi' ve Faktör 3'te 'Genel Yetenek' başlığı altındaki maddeler belirgin bir şekilde ayrıldı̆̆ından Faktör 2 ve Faktör 3'ün isimleri değiştirilmemiştir. Faktör 1 ise 'Etik Odaklı Hemşirelik Bakımı ve Mesleki Gelişim' olarak isimlendirilmiştir (Tablo 1).

Hemşirelik Yeterliliğini Holistik Değerlendirme Ölçeğinin üç faktörlü çözümlemesinde faktör 1'in özdeğeri 21.96 açıklanan varyansı \% 61.01, faktör 2'nin özdeğeri 2.49 açıklanan varyansı \% 6.92, faktör 3'ün özdeğeri 1.57 açıklanan varyansı \% 4.36'dır. Ölçeğin toplam açıklanan varyans değeri \%72.30'dur.

\section{Ölçek Maddelerinin Tanımlayıcı Özellikleri}

Ölçekteki maddelere verilen yanıtların ortalamaları 5.04 ile 5.89 arasında değişmektedir. En yüksek ortalamaya sahip ölçek maddesi 'Genel Yetenek' başlığı altındaki 7. maddedir. En düşük ortalamaya sahip madde ise 'Hemşirelik Eğitimi ve Yönetimi' başlığı altındaki 6. maddedir.

\section{İç Tutarlılık Analizleri}

$\mathrm{Bu}$ araştırmada Hemşirelik Yeterliliğini Holistik Değerlendirme Ölçeğinin iç tutarlılığını değerlendirmek için madde analizi ve test yarılama analizi yapılmış, Cronbach Alfa katsayısı incelenmiştir. Madde analizinde her bir maddenin toplam puan ile korelasyonuna bakılmıştır. Ayrıca, ölçekten madde çıkarıldıktan sonra ortaya çıkan Cronbach Alfa değeri değerlendirilmiştir.

Tablo 2. Hemşirelik Yeterliliğini Holistik Değerlendirme Ölçeği Madde Analiz Sonuçları

\begin{tabular}{|r|l|l|l|l|}
\hline Maddeler & $\begin{array}{l}\text { Madde } \\
\text { Çıktığında } \\
\text { Ölçek } \\
\text { Ortalaması }\end{array}$ & $\begin{array}{l}\text { Madde } \\
\text { çıktığınd } \\
\text { a Ölçeğin } \\
\text { Varyansı }\end{array}$ & $\begin{array}{l}\text { Madde - } \\
\text { Toplam } \\
\text { Puan } \\
\text { Korelasyon } \\
\text { u }\end{array}$ & $\begin{array}{l}\text { Madde Çıktı̆ı̆ında } \\
\text { Cronbach Alfa } \\
\text { Değerleri }\end{array}$ \\
\hline Genel Yetenek (1) & 192.53 & 1061.14 & 0.59 & 0.98 \\
\hline Genel Yetenek (2) & 192.62 & 1056.90 & 0.66 & 0.98 \\
\hline Genel Yetenek (3) & 192.47 & 1064.07 & 0.62 & 0.98 \\
\hline Genel Yetenek (4) & 192.57 & 1057.37 & 0.66 & 0.98 \\
\hline Genel Yetenek (5) & 192.61 & 1060.92 & 0.65 & 0.98 \\
\hline Genel Yetenek (6) & 192.50 & 1065.07 & 0.57 & 0.98 \\
\hline Genel Yetenek (7) & 192.12 & 1073.37 & 0.51 & 0.98 \\
\hline $\begin{array}{r}\text { Hemşirelik Eğitimi } \\
\text { ve Yönetimi (1) }\end{array}$ & 192.72 & 1049.24 & 0.76 & 0.98 \\
\hline $\begin{array}{c}\text { Hemşirelik Eğitimi } \\
\text { ve Yönetimi (2) }\end{array}$ & 192.63 & 1050.99 & 0.77 & 0.98 \\
\hline $\begin{array}{r}\text { Hemşirelik Eğitimi } \\
\text { ve Yönetimi (3) }\end{array}$ & 193.13 & 1046.38 & 0.71 & 0.98 \\
\hline $\begin{array}{r}\text { Hemşirelik Eğitimi } \\
\text { ve Yönetimi (4) }\end{array}$ & 193.16 & 1037.61 & 0.77 & 0.98 \\
\hline $\begin{array}{r}\text { Hemşirelik Eğitimi } \\
\text { ve Yönetimi (5) }\end{array}$ & 192.75 & 1050.35 & 0.76 & 0.98 \\
\hline $\begin{array}{c}\text { Hemşirelik Eğitimi } \\
\text { ve Yönetimi (6) }\end{array}$ & 192.97 & 1050.50 & 0.72 & 0.98 \\
\hline $\begin{array}{r}\text { Hemşirelik Eğitimi } \\
\text { ve Yönetimi (7) }\end{array}$ & 192.92 & 1044.72 & 0.76 & 0.98 \\
\hline $\begin{array}{r}\text { Hemşirelik Ĕğitimi } \\
\text { ve Yönetimi (8) }\end{array}$ & 192.95 & 1044.07 & 0.76 & 0.98 \\
\hline $\begin{array}{c}\text { Hemşirelik Eğitimi } \\
\text { ve Yönetimi (9) }\end{array}$ & 192.69 & 1047.52 & 0.78 & 0.98 \\
\hline $\begin{array}{r}\text { Etik Odaklı } \\
\text { Uygulama (1) }\end{array}$ & 192.31 & 1049.95 & 0.84 & 0.98 \\
\hline
\end{tabular}

Tablo 2. Hemşirelik Yeterliliğini Holistik Değerlendirme ölçeği Madde Analiz Sonuçları (devamı)

\begin{tabular}{|c|c|c|c|c|}
\hline Maddeler & $\begin{array}{l}\text { Madde } \\
\text { Çıktığında } \\
\text { Ölçek } \\
\text { Ortalaması }\end{array}$ & $\begin{array}{l}\text { Madde } \\
\text { Çıktığınd } \\
\text { a Ölçeğin } \\
\text { Varyansı }\end{array}$ & $\begin{array}{l}\text { Madde - } \\
\text { Toplam } \\
\text { Puan } \\
\text { Korelasyo } \\
\text { nu }\end{array}$ & $\begin{array}{l}\text { Madde } \\
\text { Çıktığında } \\
\text { Cronbach Alfa } \\
\text { Değerleri }\end{array}$ \\
\hline $\begin{array}{l}\text { Etik } \\
\text { Uygulama (2) }\end{array}$ & 192.33 & 1049.30 & 0.82 & 0.98 \\
\hline $\begin{array}{r}\text { Etik Odaklı Uygulama } \\
\text { (3) }\end{array}$ & 192.39 & 1052.31 & 0.76 & 0.98 \\
\hline $\begin{array}{r}\text { Etik Odaklı Uygulama } \\
(4) \\
\end{array}$ & 192.33 & 1051.66 & 0.82 & 0.98 \\
\hline $\begin{array}{r}\text { Etik Odaklı Uygulama } \\
(5) \\
\end{array}$ & 192.21 & 1053.57 & 0.79 & 0.98 \\
\hline $\begin{array}{r}\begin{array}{r}\text { Etik Odaklı Uygulama } \\
(6)\end{array} \\
\end{array}$ & 192.19 & 1054.67 & 0.82 & 0.98 \\
\hline $\begin{array}{r}\text { Etik Odaklı Uygulama } \\
\text { (7) }\end{array}$ & 192.27 & 1048.57 & 0.82 & 0.98 \\
\hline $\begin{array}{r}\text { Etik Odaklı Uygulama } \\
\text { (8) }\end{array}$ & 192.30 & 1047.13 & 0.81 & 0.98 \\
\hline $\begin{array}{r}\text { Etik Odaklı Uygulama } \\
(9)\end{array}$ & 192.33 & 1053.69 & 0.76 & 0.98 \\
\hline $\begin{array}{r}\text { Ekip İçinde Hemşirelik } \\
\text { Bakımı (1) }\end{array}$ & 192.49 & 1046.36 & 0.83 & 0.98 \\
\hline $\begin{array}{r}\text { Ekip İçinde Hemşirelik } \\
\text { Bakımı (2) } \\
\end{array}$ & 192.41 & 1048.35 & 0.82 & 0.98 \\
\hline $\begin{array}{r}\text { Ekip iç̧inde Hemşirelik } \\
\text { Bakımı (3) } \\
\end{array}$ & 192.38 & 1048.92 & 0.83 & 0.98 \\
\hline $\begin{array}{r}\text { Ekip İçinde Hemşirelik } \\
\text { Bakımı (4) }\end{array}$ & 192.44 & 1047.93 & 0.83 & 0.98 \\
\hline $\begin{array}{r}\text { Ekip Iç̧inde Hemşirelik } \\
\text { Bakımı (5) } \\
\end{array}$ & 192.35 & 1045.90 & 0.84 & 0.98 \\
\hline $\begin{array}{r}\text { Ekip Iç̧inde Hemşirelik } \\
\text { Bakımı (6) } \\
\end{array}$ & 192.35 & 1049.49 & 0.84 & 0.98 \\
\hline $\begin{array}{r}\text { Ekip İçinde Hemşirelik } \\
\text { Bakımı (7) }\end{array}$ & 192.15 & 1050.31 & 0.81 & 0.98 \\
\hline Mesleki Gelişim (1) & 192.54 & 1047.73 & 0.80 & 0.98 \\
\hline Mesleki Gelişim (2) & 192.42 & 1048.98 & 0.84 & 0.98 \\
\hline Mesleki Gelişim (3) & 192.53 & 1050.81 & 0.76 & 0.98 \\
\hline Mesleki Gelişim (4) & 192.51 & 1048.59 & 0.76 & 0.98 \\
\hline
\end{tabular}

Araştırmada ölçeğin tamamına ait Cronbach Alfa değeri 0.98 olarak bulunmuştur. Ayrıca, tüm alt boyutlar için Cronbach Alfa değeri hesaplanmış ve bu değerler 'Etik Odaklı Hemşirelik Bakımı ve Mesleki Gelişim' olarak isimlendirilen faktör 1 için 0.98; 'Hemşirelik Eğitimi ve Yönetimi' olarak isimlendirilen faktör 2 için 0.93; 'Genel Yetenek' olarak isimlendirilen faktör 3 için 0.90 olarak bulunmuştur.

Ölçekten madde çıkarıldığında ortaya çıkan Cronbach Alfa değerleri incelendiğinde ölçeğin Cronbach Alfa değeri yükselmemektedir. Ölçeğin madde-toplam korelasyon değerlerine bakıldığında madde-toplam puan korelasyon değerinin 0.51 ile 0.84 arasında değiştiği görülmektedir (Tablo 2).

Bir ölçeğin iç tutarlılığını değerlendirmenin yollarından biri olan test yarılama yöntemi Hemşirelik Yeterliliğini Holistik Değerlendirme Ölçeğine uygulanmıştır. Test yarılama işlemi sonucunda hem ölçeğin tamamına ait hem de her iki yarısına ait Cronbach Alfa güvenilirlik katsayısı hesaplanmıştır. Testin bütününe ilişkin güvenilirlik katsayısını elde etmek için Spearman Brown tarafından geliştirilen bir eşitlikten yararlanılmıştır. 
Tablo 3. Hemşirelik Yeterliliğini Holistik Değerlendirme ölçeği Test Yarılama Analizleri ve Cronbach Alfa Katsayıları

\begin{tabular}{|l|l|}
\hline \multicolumn{2}{|l|}{ Hemşirelik Yeterliliğini Holistik Değerlendirme ölçeği } \\
\hline Toplam ölçek Cronbach Alfa katsayısı & 0.98 \\
\hline Spearman-Brown & 0.91 \\
\hline Gutmann Split-Half & 0.91 \\
\hline İlk yarı Cronbach Alfa katsayısı & $0.95\left(18^{\mathrm{a}}\right)$ \\
\hline İkinci yarı Cronbach Alfa katsayısı & $0.97\left(18^{\mathrm{b}}\right)$ \\
\hline İki yarı arasındaki korelasyon & 0.84 \\
\hline $\mathrm{n}$ & 384 \\
\hline Madde sayısı & 36 \\
\hline
\end{tabular}

Geçerlilik ve güvenilirliği yapılan HYHDÖ' de 36 madde bulunmaktadır. Ölçekte 1-16 madde birinci yarıyı (18 $\left.{ }^{\mathrm{a}}\right), 17-$ 36 madde ikinci yarıyı ( $18^{\text {b }}$ ) oluşturmuştur. Her iki yarıya ait Cronbach Alfa katsayısı hesaplanmış, ilk yarıya ait Cronbach Alfa katsayısı 0.95, ikinci yarıya ait Cronbach Alfa katsayısı 0.97 olarak bulunmuştur. Ölçeğin toplamına ilişkin Cronbach Alfa katsayısı ise 0.98 'dir. İki yarı arasındaki korelasyon değeri 0.84 'tür. Gutmann Split-Half ve Spearman-Brown testlerinin sonuçları ise 0.91 bulunmuştur.

\section{TARTIŞMA}

\section{Yapı Geçerliliği}

Bir ölçeğin ölçtüğü niteliklerin neler olduğunu belirlemek ve ölçeğin uygulandığı kişilerin aldığı puanların ne anlama geldiğini araştırmak için ölçeğin yapı geçerliliği değerlendirilir ${ }^{23}$. Bir ölçekte yapı geçerliliğini değerlendirmek üzere en fazla kullanılan yaklaşımlar faktör analizi ve bilinen grup karşılaştırmalarıdı ${ }^{24}$. Geçerlilik ve güvenilirliği yapılan ölçekte faktör analizi yöntemi kullanılmıştır ve ölçekte faktör analizinin uygulanıp uygulanamayacağını belirlemek için kullanılan KaiserMeyer-Olkin (KMO) Testi uygulanmıştır. KMO testi değişkenler arasındaki korelasyonları ve faktör analizinin uygunluğunu ölçen testtir. KMO testinin değeri 0 ile 1 aralığında olmalıdır ${ }^{25}$. KMO'nun 1'e yaklaşan değeri uygunluğunu gösterir, $0.5^{\prime}$ in altındaki değer kabul edilemez. $\mathrm{Bu}$ araştırmada KMO değeri 0.974 olarak bulunmuştur. Barlett küresellik testi ki-kare istatistik değerini verir ve anlamlıık değerine bakılır. İstenen, anlamlılık değerinin 0.05 'ten küçük olmasıdır ${ }^{21}$.

Faktör yapılandırmada her bir boyutun yüksek faktör yüküne sahip en az üç değişkene (maddeye) sahip olması gerekir. Bir maddenin kavramsal yapıyla ilgili olup olmadığına karar vermek için o maddenin faktör yükü en az 0.40 olmalıdır. Bazı bilim adamları faktör yükü olarak 0.30 değerini de kabul etmişlerdir ${ }^{21}$. HYHDÖ'de ölçeğin yapı geçerliliğini ortaya koymak için öncelikle Doğrulayıcı Faktör Analizi uygulanmıştır. Ancak, uygulama sonucunda 'Genel Yetenek' başlığı altındaki 1. maddenin tek bir faktörü oluşturduğu görülmüştür. Yapılan değerlendirmeler sonucunda ölçekten madde çıkarılmamış, ölçeğin faktör yapısını ortaya koyabilmek için Açıklayıcı Faktör Analizi uygulanmıştır. Yapılan Açıklayıcı Faktör Analizi sonucunda ölçek maddeleri üç faktörlü yapı altında toplanmıştır. Maddelere ait faktör yüklerinin de 0.54-0.82 arasında değiştiği görülmektedir.

Yapılan geçerlilik analizlerinde HYHDÖ’nün orijinal ölçekteki gibi beş faktörlü yapı göstermediği görülmüştür.
HYHDÖ’nün orijinal dili Japonca'dır ve geçerlilik ve güvenilirlik çalışmaları Japonya'daki hemşirelere uygulanan anketler sonucunda yapılan analizlerle ortaya konmuştur. HYHDÖ’nün Türkçe geçerlilik ve güvenilirlik çalışmasında ise ölçeğin yazarları tarafından oluşturulan İngilizce metin kullanılmıştır. Çevirilerin ölçeğin orijinal dilindeki anlamı tam olarak karşılayamaması, ölçeğin orjinalinin İngilizce geçerlilik ve güvenilirliğinin yapılmamış olması, kültürel farklııklar ölçeğin farklı bir faktör yapısı göstermesine sebep olarak gösterilebilir.

\section{İç Tutarlılık Analizleri}

Hemşirelik Yeterliliğini Holistik Değerlendirme Ölçeğine baktığımızda madde-toplam puan korelasyon değerlerinin 0.51 ile 0.84 arasında değiştiği gözlenmektedir. Herhangi bir maddenin madde-toplam korelasyon katsayısı çok düşükse ya da negatifse maddenin ölçekte gereksiz olduğu ve ölçekten çıkartılması gerektiği yorumu yapılabilir. Kaba bir yaklaşımla katsayının 0.30 'dan büyük olması istenen bir durumdur ${ }^{26}$. Hemşirelik Yeterliliğini Holistik Değerlendirme Ölçeğinde maddelerin hepsinin madde-toplam puan korelasyonu 0.30 'dan büyüktür. Bu durum ölçek maddelerinin güvenilirlik açısından uygun olduğunu göstermektedir. Ölçeğin madde analizlerini yaparken madde-toplam puan korelasyonu dışında maddenin ölçekten çıkartılması durumunda güvenilirlik katsayısının değişimi de incelenir. Madde ölçekten çıkartıldığında alfa katsayısı ölçeğin tümü için hesaplanan alfa katsayısından büyükse "maddenin güvenilirliği azalttığı ve ölçekten çıkarılması gerektiği" şeklinde yorumlanır ${ }^{26}$. Hemşirelik Yeterliliğini Holistik Değerlendirme Ölçeğindeki maddeler ölçekten çıkarıldığında alfa katsayısının değişimine baktığımızda hesaplanan değerin artmadığı görülmektedir. Bu durum ölçek maddeleri arasındaki iç tutarlılığın yüksek olduğunu göstermektedir ve ölçek maddelerinin hiçbiri ölçekten çıkarılmamıştır.

Ölçek geçerlilik güvenirliklerinde farklı iç tutarlılık güvenilirlik saptama yöntemleri kullanılmaktadır. Test yarılama yöntemi bunlardan biridir. Ölçeğin her iki yarısının birbirine paralel olduğu varsayımı üzerine kuruludur; yani her iki yarının ortalama ve varyanslarının eşit olduğunu kabul eder. Sonuçta elde edilen güvenilirlik katsayısına "eşdeğer iki yarı güvenilirliği" denir. Eğer ölçek tek boyuttan oluşuyorsa ölçeğin tümü için uygulanabilir ya da ölçeğin alt boyutları varsa her alt boyut için kendi içinde bir bütün olarak kabul edilip alt boyutlar için de uygulanabilir ${ }^{27}$. Ölçeğin bütününe ilişkin güvenilirlik katsayısını elde etmek için Spearman-Brown tarafından geliştirilen bir eşitlikten yararlanılmaktadır ${ }^{27}$.

Geçerlilik ve güvenilirliği yapılan Hemşirelik Yeterliliğini Holistik Değerlendirme Ölçeğinde 1-16 madde birinci yarıyı (18a), 17-36 madde ikinci yarıyı (18b) oluşturmuştur. Her iki yarıya ait Cronbach Alfa katsayısı hesaplanmış, ilk yarıya ait Cronbach Alfa katsayısı 0.95 ikinci yarıya ait Cronbach Alfa katsayısı 0.97 olarak bulunmuştur. İki yarı arasındaki korelasyon değeri 0.84 'tür. Gutmann Split-Half ve Spearman-Brown testlerinin sonuçları ise 0.91'dir. Bu durum HYHDÖ’nin güvenilirliğinin yüksek olduğunu göstermektedir. 
Ölçeğin iç tutarlılık güvenilirliğini sınamak için Cronbach Alfa iç tutarlıık katsayısı ( $r$ ) hesaplanır ${ }^{21}$. Cronbach Alfa katsayısı bir ölçekte maddelere verilen cevapların ikiden fazla seçenekli olması durumunda soruların birbiri ile benzerliğini, yakınlığını ortaya koyan katsayıdır. Literatürde, Cronbach Alfa değerine farklı yaklaşımlar mevcuttur. Genel olarak Alfa değerinin 0.70 'den büyük olması istenen bir durumdur, 0.50 'den küçük olması kabul edilemez. Bazı kaynaklarda alt sınır 0.40 olarak ifade edilmektedir ${ }^{21,26,28}$. Bu araştırmada Hemşirelik Yeterliliğini Holistik Değerlendirme Ölçeği'nin Cronbach Alfa güvenilirlik katsayısı 0.98 olarak bulunmuştur. Ayrıca, ölçeğin tüm alt boyutlarına ait Cronbach Alfa değeri hesaplanmıştır. Bu değerler 'Etik Odaklı Hemşirelik Bakımı ve Mesleki Gelişim' alt boyutu için 0.98; 'Hemşirelik Eğitimi ve Yönetimi' alt boyutu için 0.93 ve 'Genel Yetenek' alt boyutu için 0.90 olarak bulunmuştur. HYHDÖ'nin genel ve tüm alt boyutlarında Cronbach Alfa değerinin yüksek olduğu görülmektedir. Bu durum ölçeğin yüksek güvenilirliğe sahip olduğunu göstermektedir. Ayrıca, yapılan diğer güvenilirlik analizleri de (madde puanlarının tanımlayıcı özellikleri, test yarılama analizi) HYHDÖ’nin güvenilirliğinin yüksek olduğuna işaret etmektedir.

\section{SONUÇ ve ÖNERILER}

Yapılan geçerlilik ve güvenilirlik analizleri sonucunda Hemşirelik Yeterliliğini Holistik Değerlendirme Ölçeğinin Türk toplumu için hemşirelerin yeterliliğini değerlendirmede geçerli ve güvenilir bir ölçme aracı olduğu sonucuna varılmıştır. Araştırma sonucuna göre; bu ölçeğin farklı kurum ve kliniklerde çalışan hemşirelerce kullanılması, bu ölçekle hemşirelerin yeterliliğinin belirli aralıklarla değerlendirilmesi ve sonuçların karşılaştırılması önerilmektedir. Ayrıca, yeterliliği değerlendiren farklı ölçme araçlarının geçerlilik ve güvenilirliğinin yapılması ve en uygun ölçme aracının belirlenmesi ile hemşirelerin yeterliliğini etkileyen faktörlerin belirlenebileceği düşünülmektedir.

Etik Kurul Onayı: Adnan Menderes Üniversitesi Tıp Fakültesi Girişimsel Olmayan Klinik Araştırmalar Etik Kurulundan yazılı izin alınmıştır (14-06-2016/882). Araştırmanın yürütüldüğü hastanelerden yazılı izin alınmıştır.

Çıkar Çatışması: Bildirilmemiştir.

Finansal Destek: Bu araştırma yüksek lisans tez çalışması olup Aydın Adnan Menderes Üniversitesi Bilimsel Araştırma Projeleri Birimi tarafından ASYO-16004 proje numarası ile desteklenmiştir.

Katılımcı Onamı: Araştırmaya katılan hemşirelere çalışmanın amacı anlatılmış, çalışmaya katılmada gönüllülük ilkesine bağlı kalınmış ve çalışmaya katılanlardan sözel onam alınmıştır.

Yazar katkıları:

Araştırma dizaynı: GT, ES

Veri Toplama: ES

Veri Analizi: GT, ES

Makale Yazımı: ES, GT

Teşekkür: Teşekkür: Araştırmanın gerçekleştirilmesi için gerekli maddi desteği sağlayan Aydın Adnan Menderes Üniversitesi Bilimsel Araştırma Projeleri Birimi'ne, istatistiksel analizlerde bilgi ve görüşleriyle katkıda bulunan
Ege Üniversitesi Tıp Fakültesi Biyoistatistik ve Tıbbi Bilişim Anabilim Dalı'na, ölçeğin Türkçe geçerlilik ve güvenilirliğinin yapılmasına izin veren Takase ve Teraoka'ya, ölçeğin çevirisine katkıda bulunan tüm uzmanlara, araştırmanın yürütüldüğü hastanenin yöneticilerine ve yoğun çalışma saatlerine rağmen zaman ayırıp araştırmaya katılan tüm hemşirelere katkılarından dolayı teşekkürlerimizi sunarız.

Ethics Committee Approval: Approval was obtained from the Non-interventional Clinical Research Ethics Committee of Adnan Menderes University (14-06-2016/882). Written permission was obtained from the hospitals where the study was conducted.

Conflict of Interest: We have no conflicts of interest on the subject and during the process of the paper.

Funding: This research is a master's thesis study supported by Aydın Adnan Menderes University Scientific Research Projects Unit (Project Number: ASYO-16004).

Exhibitor Consent: The purpose of the study was explained to the nurses participating in the study, adherence to the principle of volunteering was included in the study, and verbal consent was obtained from the participants.

Author contributions

Study design: GT, ES

Data collection: ES

Data analysis: GT, ES

Drafting manuscript: ES, GT

Acknowledgement:

We would like to thank Aydın Adnan Menderes University Scientific Research Projects Unit, which provides the financial support necessary for the realization of the research, Ege University Faculty of Medicine Department of Biostatistics and Medical Informatics, which contributes their knowledge and opinions in statistical analysis, Takase and Teraoka, which allowed the validity and reliability of the scale in Turkish, to all experts who contributed to the translation of the scale, the managers of the hospital where the research was carried out and to all nurses who took their time and participated in the study despite their busy working hours.

\section{KAYNAKLAR}

1. Jasper M. New nursing roles- implications for nursing management. Journal of Nursing Management 2005;13:93-96.

2. World Health Organization (WHO). Transforming and scaling up health professional education and training. Policy Brief on Regulation of Health Professions Education [Internet]. 2013 [Erişim Tarihi 15 Kasım 2018]. Erişim adresi: http://whoeducationguidelines.org/sites/default/files /uploads.

3. Kendall-Gallagher D, Blegen MA. Competence and certification of registered nurses and safety of patients in intensive care units. American Journal of Critical Care 2009;18(2):106-16.

4. Benner P. Issues in competency-based testing. Nursing Outlook 1982;30(5):303-09. 
5. While AE. Competence versus performance: Which is more important? Journal of Advanced Nursing 1994;20:525-31.

6. Nagelsmith L. Competence: An evolving concept. The Journal of Continuing Education in Nursing 1995;26(6):245-48.

7. Del Bueno DJ. Evaluation: Myths, mystiques, and obsessions. Journal of Nursing Administration 1990;20(11):4-7.

8. Del Bueno DJ, Weeks L, Brown-Stewart P. Clinical assessment centers: A cost-effective alternative for competency development. Nursing Economics 1987;5(1):21-26.

9. Gurvis JP, Grey MT. The anatomy of a competency. Journal of Nursing Staff Development 1995;11:24752.

10. Westera W. Competences in education: A confusion of tongues. Journal of Curriculum Studies 2001;33(1):7588.

11. WHO. Global standards for the initial education of professional nurses and midwives. Nursing \& Midwifery Human Resources for Health 2009;8-29.

12. Messick S. The psychology of educational measurement. Journal of Educational Measurement 1984;3(21):215-38.

13. Karahan A, Kav S. Hemşirelikte mesleki yetkinlik. Hacettepe Üniversitesi Hemşirelik Fakültesi Derg. 2018;5(2):76-84.

14. Yüceer S, Demir SG. Yoğun bakım ünitesinde nozokomiyal enfeksiyonların önlenmesi ve hemşirelik uygulamaları. Dicle Tıp Derg. 2009;36(3):226-32.

15. Güleser GN, Taşçı S. Onkolojide sık kullanılan santral venöz kateterleri ve bakımı. Fırat Üniversitesi Sağlık Bilimleri Tıp Derg. 2009;23(1):47-51.

16. İncirkuş K, Nahcivan NÖ. Kronik Hastalık Bakımını Değerlendirme Ölçeği-Hasta Formu'nun Türkçe versiyonunun geçerlik ve güvenirliği. DEÜ Hemşirelik Yüksekokulu Elektronik Derg. 2011;4(1):102-09.

17. İspir Ö, Duygulu S. Hemşirelik uygulamaları üzerinde kontrol kavramı. Hemşirelikte Eğitim ve Araştırma Derg. 2018;15(3):181-85.

18. Erbil N, Bakır A. Meslekte profesyonel tutum envanterinin geliştirilmesi. Uluslararası İnsan Bilimleri Derg. 2009;6(1):290-02.

19. Takase M, Teraoka S. Development of the holistic nursing competence scale. Nursing and Health Sciences 2011;13:396-03.

20. Aydin A, Hiçdurmaz D. Holistic nursing competence scale: Turkish translation and psychometric testing. Int Nurs Rev. 2019 Sep;66(3):425-33.

21. Şencan H. Sosyal ve Davranışsal Ölçümlerde Güvenilirlik ve Geçerlilik. 1. Basım. Ankara:Seçkin Yayıncılık; 2005.

22. Yurdugül H. Ölçek geliştirme çalışmalarında kapsam geçerliği için kapsam geçerlik indekslerinin kullanılması. In:15. Ulusal Eğitim Bilimleri Kongresi Bildiri Kitabı; 2005; 1-6.

23. Erkuş A. Psikometri Üzerine Yazılar. 1. Basım. Ankara: Türk Psikologlar Derneği Yayınları; 2003.
24. Aksayan S, Gözüm S. Kültürlerarası ölçek uyarlaması için rehber II: Psikometrik özellikler ve kültürlerarası karşılaştırma. Hemşirelikte Araştırma Geliştirme Derg. 2003;1:3-14.

25. Yaşlıoğlu M.M. Sosyal bilimlerde faktör analizi ve geçerlilik: Keşfedici ve doğrulayıcı faktör analizlerinin kullanılması. İstanbul Üniversitesi iş̧letme Fakültesi Derg. 2017;46:74-85.

26. Şenocak M. Temel Kavramlar ve Klinik Biyoistatistik. 1. Basım. İstanbul:Nobel Tıp Kitabevleri; 2009.

27. Aker S, Dündar C, Pekşen Y. Ölçme araçlarında iki yaşamsal kavram: Geçerlik ve güvenirlik. OMÜ Tıp Derg. 2005;22(1):50-60.

28. Tavşancıl E. Tutumların Ölçülmesi ve SPSS ile Veri Analizi. 3.Basım. Ankara: Nobel Yayın Dağıtım; 2006. 